\title{
A PROFILE OF EYE-HAND COORDINATION AND FORM CONSTANCY IN PERFORMANCE DANCESPORT
}

\author{
Mihaela ZAHIU ${ }^{1 *}$, Sabina MACOVEI ${ }^{1}$, Radu PREDOIU ${ }^{1}$, Costinel MIHAIU ${ }^{2}$, \\ Maria GRIGORE ${ }^{3}$

\footnotetext{
${ }^{1}$ National University of Physical Education and Sport, Faculty of Physical Education and Sport, Bucharest, Romania

${ }^{2}$ University of Bucharest, Department of Physical Education and Sport, Bucharest, Romania

${ }^{3}$ Ecological University, Faculty of Physical Education and Sport, Bucharest, Romania *Corresponding author: mihaela.zahiu@gmail.com
}

DOI: 10.35189/iphm.icpesk.2019.54

\begin{abstract}
Dancesport has become an activity that challenges more and more the limits of athletes, both in motor and psychological terms. The complexity and completeness of the training process largely stresses the psychological side, with influences equally coming from the technical, choreographic, artistic, physical and theoretical preparation. As any other complex activity, dancesport is performed under the auspices of rigorous control of the central nervous system, in a triadic (bio-psycho-social) sense that defines the dancer, given the demands of the activity. The higher and higher competitive requirements involve psychological training based on investigating the profile of some mental skills that guide the individualisation of training. The purpose of this paper is to investigate the characteristics of dancers' psychological profile, from the perspective of their visual discrimination and eye-hand coordination abilities. Both aspects are required in training and competitions. This ascertaining research was based on the test method and used, as investigation and assessment tools, the Form Constancy Test (a component of $\mathrm{CAS}^{++}$) and two eye-hand coordination subtests, Tracing and Dotting, from the MacQuarrie Test for Mechanical Ability. The tests were conducted in collaboration with the UNEFS Laboratory of Psychology and Psychomotricity, with the participation of 30 competitive dancers, some of them being members of the National Dancesport Team. The test results were analysed using the statistical method. We believe that the obtained results are relevant to establish a more effective strategy for conducting psychological training and can represent a starting point for conducting further tests aimed at other psychological components.
\end{abstract}

Keywords: dancesport, visual discrimination, eye-hand coordination, psychomotricity.

\section{Introduction}

Dance, as a form of expression, nonverbal communication and leisure-time or competitive activity, has accompanied human existence throughout its anthropological evolution (Mackrell, 2019). Regardless of the way of practice, dance can be considered as an aesthetic activity with an autoplastic role for the human body (Epuran, 2006).

In the highly varied typology of dance, dancesport has emerged as a competitive activity, increasingly gaining importance over time. The development of the field, which equally combines sports activity and art, relies on specific features that establish dancesport as a sports discipline (Năstase, 2011, p. 15; Jeleașcov, 2006).

Generally speaking, dance is a motor activity that requires very good control of the body. Referring to dancesport, we should note the levels of excellence in the manifestation of motricity, as a synthesis of biological and psychological capabilities. From this perspective, dancesport requires a certain profile of the motor ability, within which the coordination ability plays a major role. Actually, due to its way of engaging in the performance of movements, coordination is considered as an absolute prerequisite for the most accurate possible execution of the motor programme (Manno, 1992, p. 152).

Also, given that coordination is a complex skill, it can be considered as a qualitative feature of the motor performance, which cannot be measured, but only conventionally assessed (Șerbănoiu, 2002, p. 99).

For most sports disciplines, coordination plays an important role in achieving sports performance (Ackland, Elliot, \& Bloomfield, 2009, p. 320).

Difficulties in the manifestation of coordination are negatively reflected in the estimation of space-time aspects, in segmental synchronisation and kinaesthetic differentiation, which reduces the economy and efficiency of the gesture.

Coordination, as a complex skill, has several subcategories listed by Blume (1981, cited by Manno, 1992, p. 157):

- movement sequencing and combining ability;

- kinaesthetic differentiation ability;

- $\quad$ space-time orientation ability; 
- $\quad$ rhythm ability;

- balance ability;

- movement transformation ability;

- motor reaction ability.

This classification includes an extremely important ability for movement coordination, namely the space-time orientation ability. It intervenes in the execution of movements by controlling several aspects, such as:

- changes in body and segment positions and their orientation into work planes and directions;

- correct estimation of depths and heights relative to fixed or moving objects and/or other people;

- correct estimation of rotational directions;

- $\quad$ estimation of individual movement speed and its relation to surrounding objects and/or partners;

- movement acceleration or deceleration according to the situation;

- $\quad$ use of inertia and centrifugal force in fast turns and circular movements (Macovei, 2018, p. 128).

The manifestation of spatial perceptions ensures orientation into the surrounding environment, and their importance in motor activities is defining for the interaction with partners, objects around, the space where the movement is performed. However, we highlight that these spatial perceptions are closely related to time perceptions (Epuran \& Stănescu, 2010, pp. 210-211). Educating space-time perceptions is thought to be crucial for the psychomotor development and represents an essential source for designing the cognitive model of the external environment (Mitrache \& Tüdös, 2004, p. 35). Information about the environment and information about the parts of the body and their evolution in motion condition the control and execution of characteristics relating to direction, trajectory, range, planes and axes (Macovei, 2011).

In dancesport, space-time perceptions are decisive for making choreography and moving on the dance floor, given that several couples are together in this area. According to the competition rules, the way of moving on the dance floor is appreciated by the judging panel or penalised if there are interferences between couples. Actually, all spatial features of the objects described by form perception, size perception, distance and three-dimensionality can be found in dancesport (Mitrache \& Tüdös, 2004, p. 37).

\section{Purpose and premise}

We have started from the premise that dancesport is a complex motor activity that requires special psychomotor skills.

The purpose of this paper is to investigate the characteristics of dancers' psychological profile, from the perspective of their visual discrimination and eye-hand coordination abilities. Both aspects are required in training and competitions.

\section{Material and Methods}

This ascertaining research was based on the test method and used, as investigation and assessment tools, the Form Constancy Test (a component of $\mathrm{CAS}^{++}$) and two eye-hand coordination subtests, Tracing and Dotting, from the MacQuarrie Test for Mechanical Ability.

In the literature, there are several form perception tests. The most commonly used items refer to form constancy, form-background discrimination and the perception of details. To test the dancers, we assessed form constancy, namely their high-level visual discrimination ability. This involves recognising forms, objects having the same shape, even if their size or position changes (Miclea, Porumb, Cotârle, \& Albu, 2009, pp. 370-371).

The MacQuarrie Test for Mechanical Ability is a paper-and-pencil test with good predictive values for success in mechanical professions. It includes 7 subtests, but we used only two of them, namely Tracing and Dotting (Luca, 2010, pp. 23-27). Both subtests are against the clock: the time for Tracing is 50 seconds, and for Dotting, 30 seconds. The number of shapes matched within the set timeframe is counted. These subtests are aimed to measure the eye-hand coordination ability (implicitly the space-time orientation ability), and we believe they are efficient for dancers, who, from a visual standpoint, must orient specifically on the dance floor.

The tests were conducted in collaboration with the UNEFS Laboratory of Psychology and Psychomotricity, with the participation of 30 competitive dancers (15 female and 15 male), some of them being members of the National Dancesport Team. The test results were analysed using the statistical method, and the calculated indicators were: arithmetic mean, median, standard deviation, coefficient of variation, independent t-test. 


\section{Results}

\section{Results for the Form Constancy Test}

In this test, the 30 subjects achieved scores ranging from 4 (the minimum possible value is 0 ) to 12 points (the maximum possible value), the average score being 10.0. The value of the coefficient of variation indicates a high homogeneity of the group. The score achieved by male subjects (10.4) is higher than that achieved by female subjects (9.7), but is not statistically significant, which is confirmed by the independent t-test (calculated value 1.102, $\mathrm{p}$-value $=0.283$, so higher than 0.05). The results for this test are shown in Table 1 .

Table 1. Form Constancy - Raw scores

\begin{tabular}{|c|c|c|c|c|}
\hline \multirow{2}{*}{\multicolumn{2}{|c|}{ Calculated indicators }} & \multirow{2}{*}{ Total } & \multicolumn{2}{|c|}{ Gender } \\
\hline & & & Male & Female \\
\hline Number of cases & & 30 & 15 & 15 \\
\hline Arithmetic mean & & 10.0 & 10.4 & 9.7 \\
\hline Median & & 11.0 & 11.0 & 11.0 \\
\hline Standard deviation & & 1.8 & 1.2 & 2.3 \\
\hline Coefficient of variation & & $18.2 \%$ & $11.4 \%$ & $23.7 \%$ \\
\hline Minimum & & 4 & 8 & 4 \\
\hline Maximum & & 12 & 12 & 12 \\
\hline \multirow{2}{*}{ Independent t-test (Male vs. Female) } & calculated t-value & - & \multicolumn{2}{|c|}{1.102} \\
\hline & $\mathrm{p}$ & - & \multicolumn{2}{|c|}{0.283} \\
\hline
\end{tabular}

Figure 1 shows the average scores for the entire sample and gender analysis.

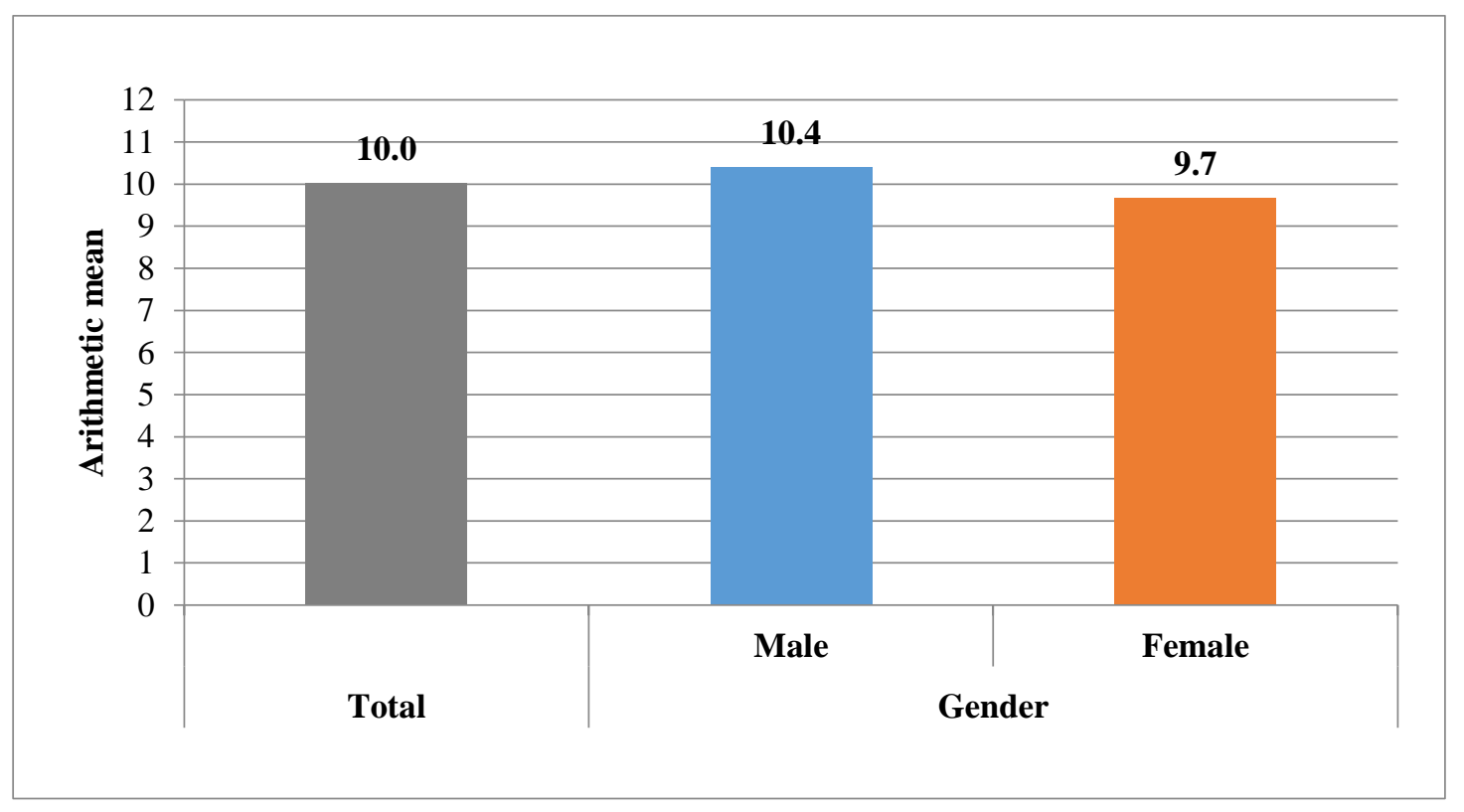

Figure 1. Form Constancy - Average raw scores

To interpret the results obtained in this test, raw scores are converted into standard levels/classes (depending on age and gender).

According to the achieved score, the subject falls into one of the 5 classes as follows:

- Class 5 - very good level of form constancy ability (the assessed person has a better performance than 93.9\% of the population);

- Class 4 - good level of form constancy ability (the assessed person has a better performance than $69.1 \%$ of the population); 
- Class 3 - moderate level of form constancy ability (the assessed person has a better performance than $30.9 \%$ of the population);

- Class 2 - poor level of form constancy ability (the assessed person has a better performance than $6.7 \%$ of the population);

- Class 1 - very poor level of form constancy ability (the assessed person has a performance that ranks him or her among the $6.7 \%$ of the population).

Thus, analysing the results of the 30 subjects by level (Table 2), we can say that over half of them $(56.7 \%)$ have a very good level, $23.3 \%$ have a good level and $16.7 \%$ have a moderate level. Only $3.3 \%$ of subjects have a very poor level of this ability (Figure 2).

Table 2. Form Constancy - Scores by level/class

\begin{tabular}{lccccccc}
\hline \multicolumn{1}{c}{ Age } & $\begin{array}{c}\text { Number of } \\
\text { cases }\end{array}$ & $\begin{array}{c}\text { Very poor } \\
(1)\end{array}$ & Poor (2) & Moderate (3) & Good (4) & $\begin{array}{c}\text { Very good } \\
(5)\end{array}$ & $\begin{array}{c}\text { Average } \\
\text { score }\end{array}$ \\
\hline $12-14$ years & $\mathbf{1}$ & 0 & 0 & 0 & 0 & 1 & $\mathbf{5 . 0 0}$ \\
$15-17$ years & $\mathbf{9}$ & 0 & 0 & 1 & 1 & 7 & $\mathbf{4 . 6 7}$ \\
$18-22$ years & $\mathbf{1 6}$ & 1 & 0 & 2 & 5 & 8 & $\mathbf{4 . 1 9}$ \\
$23-27$ years & $\mathbf{2}$ & 0 & 0 & 1 & 0 & 1 & $\mathbf{4 . 0 0}$ \\
$28-32$ years & $\mathbf{2}$ & 0 & 0 & 1 & 1 & 0 & $\mathbf{3 . 5 0}$ \\
Total & $\mathbf{3 0}$ & $\mathbf{1}$ & $\mathbf{0}$ & $\mathbf{5}$ & $\mathbf{7}$ & $\mathbf{1 7}$ & $\mathbf{4 . 3 0}$ \\
Total $(\boldsymbol{\%})$ & $\mathbf{1 0 0 \%}$ & $\mathbf{3 . 3 \%}$ & $\mathbf{0 . 0 \%}$ & $\mathbf{1 6 . 7 \%}$ & $\mathbf{2 3 . 3 \%}$ & $\mathbf{5 6 . 7 \%}$ & - \\
\hline
\end{tabular}

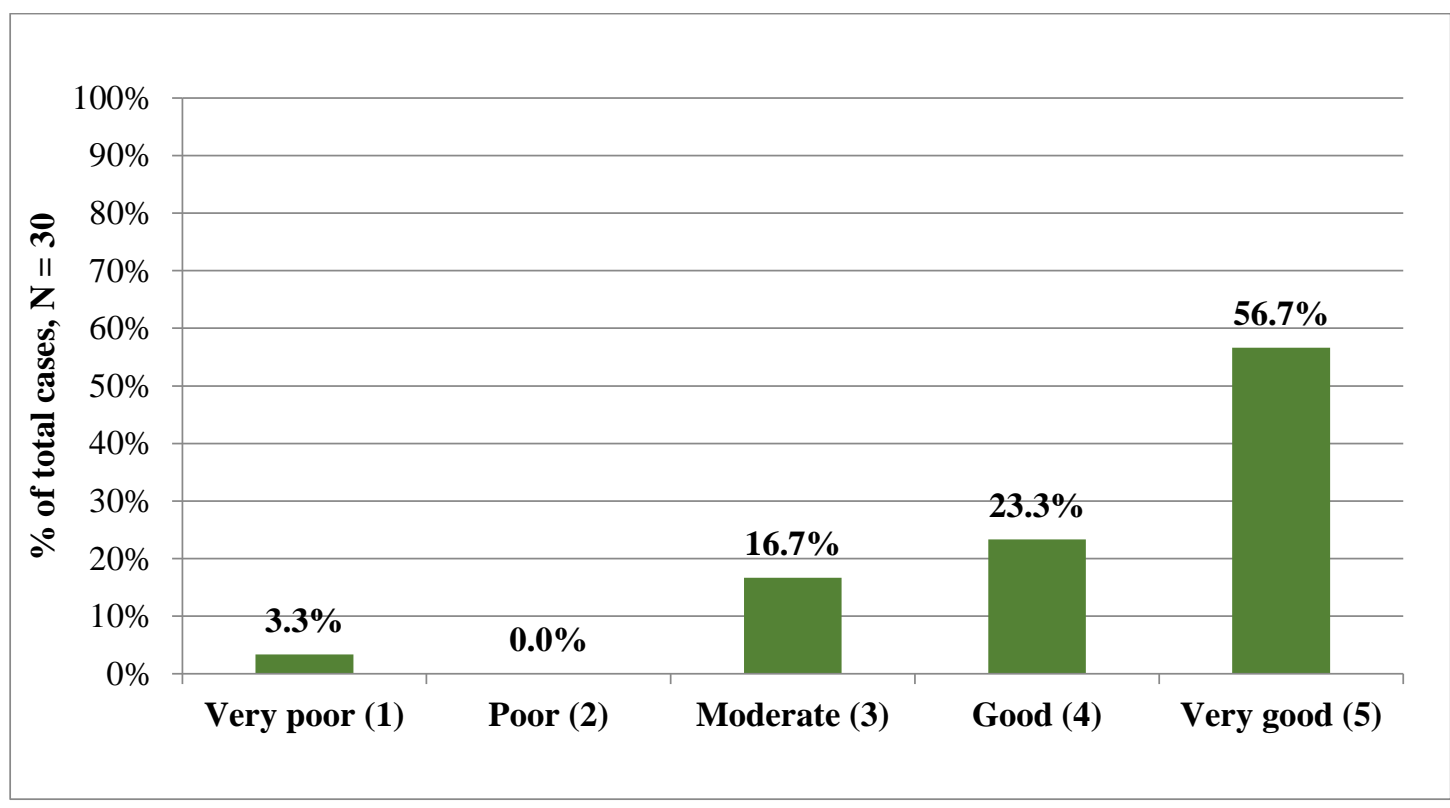

Figure 2. Form Constancy - Scores by level

- Results for the Tracing subtest

Table 3 shows the statistical results for the Tracing subtest. The 30 subjects achieved scores ranging from 33 to 80 points, the average score being 54.6. Out of the total number of subjects, the score of 80 points was achieved by 2 female subjects and 1 male subject. The value of the coefficient of variation indicates a moderate homogeneity of the group. The score achieved by female subjects (58.3) is higher than that achieved by male subjects (50.8), but is not statistically significant, which is confirmed by the independent t-test (calculated value $-1.509, \mathrm{p}$-value $=$ 0.143 , so higher than 0.05 ). 
Table 3. Tracing subtest - Raw scores

\begin{tabular}{|c|c|c|c|c|}
\hline \multirow{2}{*}{\multicolumn{2}{|c|}{ Calculated indicators }} & \multirow{2}{*}{ Total } & \multicolumn{2}{|c|}{ Gender } \\
\hline & & & Male & Female \\
\hline Number of cases & & 30 & 15 & 15 \\
\hline Arithmetic mean & & 54.6 & 50.8 & 58.3 \\
\hline Median & & 50.5 & 46.0 & 56.0 \\
\hline Standard deviation & & 14.0 & 13.4 & 13.9 \\
\hline Coefficient of variation & & $25.6 \%$ & $26.4 \%$ & $23.9 \%$ \\
\hline Minimum & & 33 & 33 & 38 \\
\hline Maximum & & 80 & 80 & 80 \\
\hline \multirow{2}{*}{ Independent t-test (Male vs. Female) } & calculated t-value & - & \multicolumn{2}{|c|}{1.509} \\
\hline & $\mathrm{p}$ & - & \multicolumn{2}{|c|}{0.143} \\
\hline
\end{tabular}

The graphical representation of arithmetic means is shown in Figure 3.

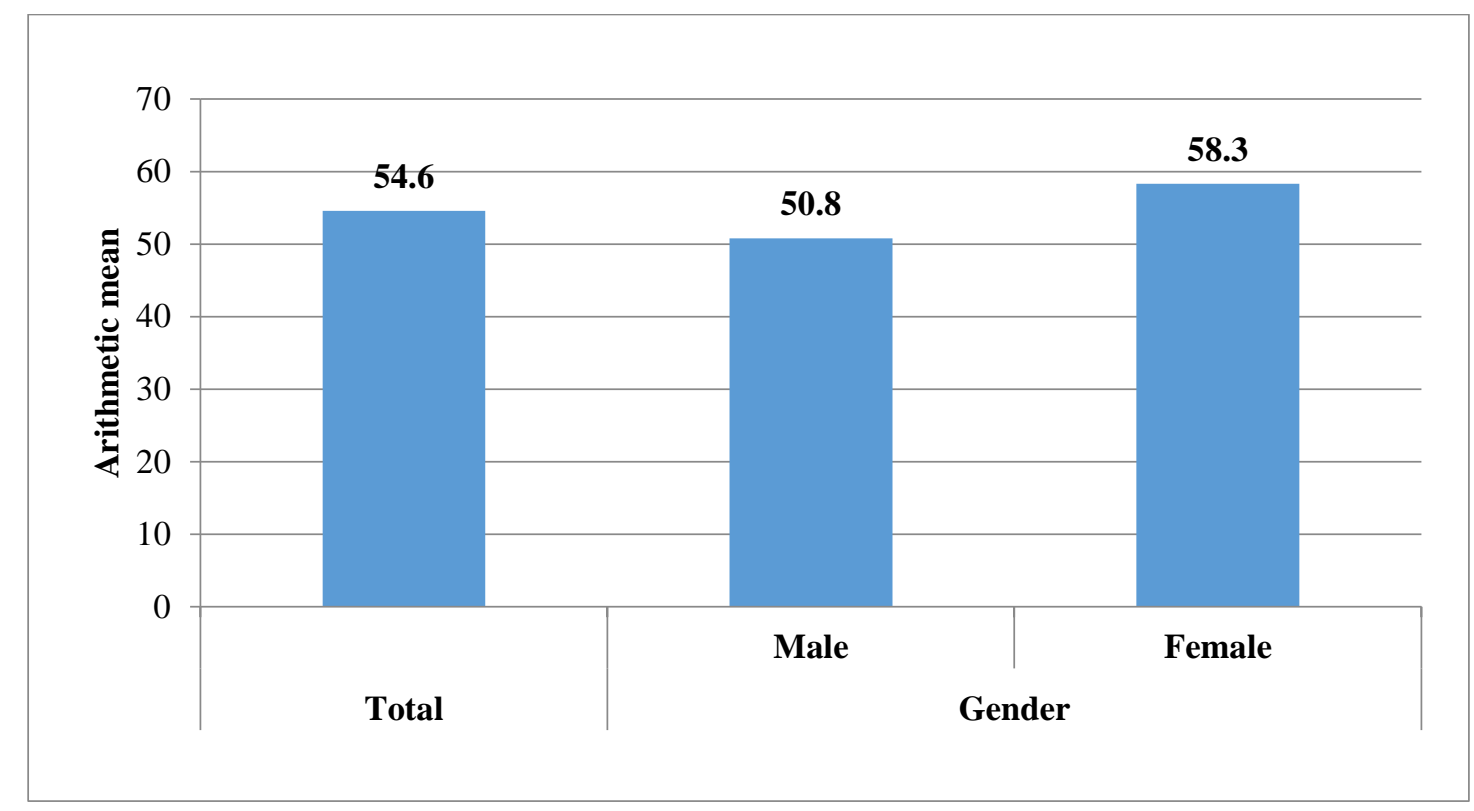

Figure 3. Tracing subtest - Average scores

Comparing the results with the standards for girls and boys, most subjects achieved very good results, $100 \%$ in the case of female dancers and $86.7 \%$ in the case of male dancers.

- $\quad$ Results for the Dotting subtest

In this subtest, the 30 subjects achieved scores ranging from 16 to 27 points, the average score being 23.1. The value of the coefficient of variation indicates a moderate homogeneity of the group. The score achieved by female subjects (23.3) is higher than that achieved by male subjects (22.9), but is not statistically significant, which is confirmed by the independent t-test (calculated value -0.409 , p-value $=0.594$, so higher than 0.05 ).

Table 4. Dotting subtest - Raw scores

\begin{tabular}{lcccc}
\hline & Calculated indicators & Total & \multicolumn{2}{c}{ Gender } \\
\cline { 3 - 5 } & & 30 & Male & Female \\
\hline Number of cases & 23.1 & 22.9 & 15 \\
Arithmetic mean & & 23.3
\end{tabular}


International Proceedings of Human Motricity/ ICPESK 2019

Supplementary Issue of Discobolul - Physical Education, Sport and Kinetotherapy Journal, 2019

Median

Standard deviation

Coefficient of variation

Minimum

Maximum

Independent t-test (Male vs. Female)
23.0

2.4

$10.1 \%$

16

27

calculated t-value

$\mathrm{p}$

$-$
22.7

2.7

$11.7 \%$

16

27

0.409

0.594
23.0

2.0

$8.7 \%$

20

27

The average scores of the group are graphically shown in Figure 4.

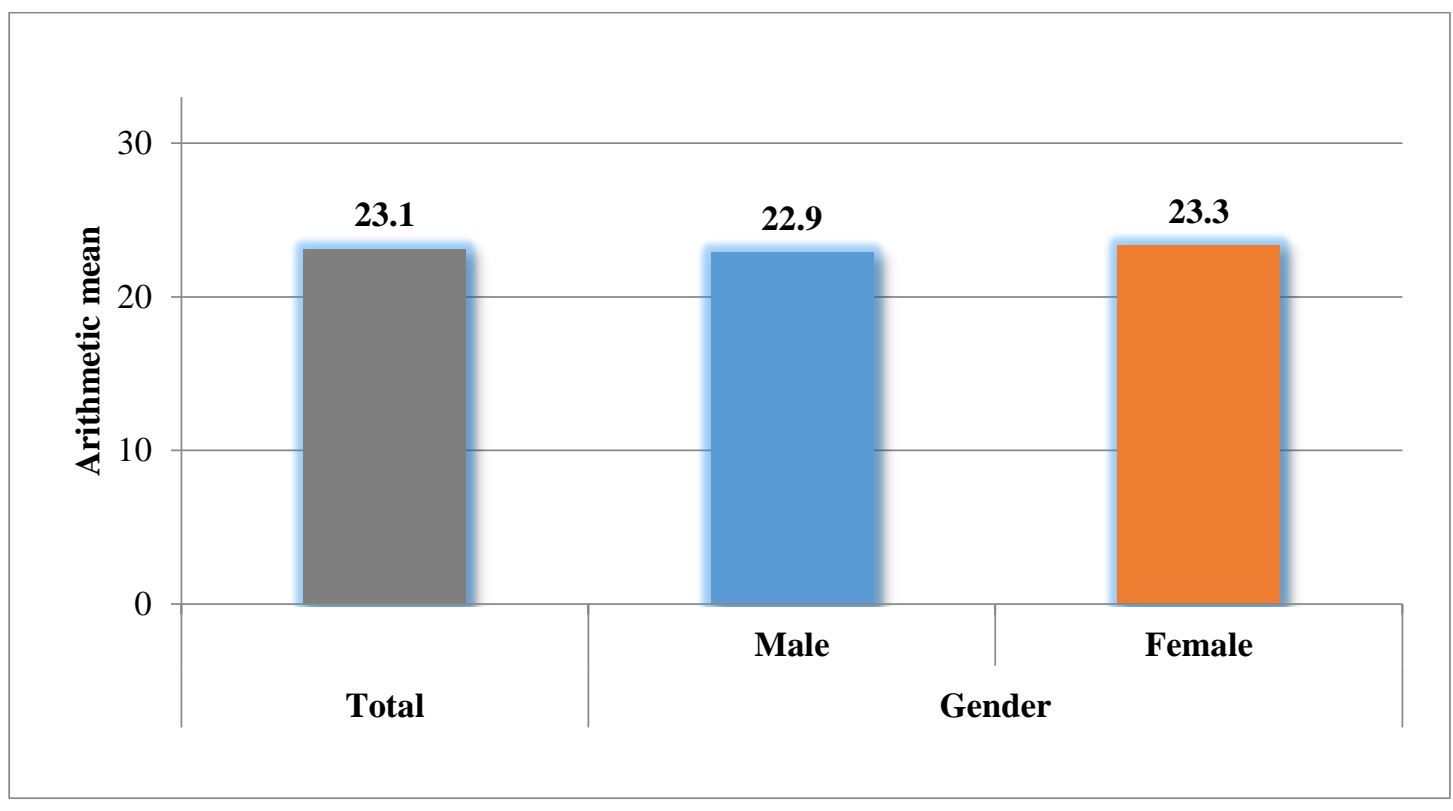

Figure 4. Dotting subtest - Average scores

\section{Conclusion}

- The study carried out reveals that the subjects, generally, have a very good development of space-time orientation ability, and this is true for both visual discrimination and eye-hand coordination abilities.

- Analysing the results for the Form Constancy Test, it can be seen that most subjects fall into the standard classes 4 and 5, which indicates abilities exceeding the average score of the normal population. The homogeneity of the group is high, which allows us to state that the practice of dancesport contributes to the development of visual discrimination ability and spatial perceptions due to the situations in which the couples of dancers are involved in both training but especially competitions.

- The same positive results are achieved for Tracing and Dotting, but these subtests highlight that the homogeneity of the group is moderate, which may also depend on the subjects' competitive experience.

- Gender analysis reveals better results for female subjects than male subjects, but the differences are not statistically significant.

- We believe that the obtained results are relevant and can represent a starting point for conducting further tests aimed at other psychological components. They can also contribute to establishing a more effective strategy for conducting psychological training.

\section{Authors' Contributions}

All authors contributed equally to this study and should be considered as main authors. 


\section{References}

Ackland, T., Elliott, B., \& Bloomfield, J. (2009). Applied anatomy and biomechanics in sport (2 ${ }^{\text {nd }}$ ed.). Human Kinetics.

Epuran, M. (2006). Caracterul autoplastic al unor activități corporale. Eseu cu aspect de "punct de vedere" [The autoplastic character of some bodily activities. An essay as a "point of view"]. Știința Sportului, 55, 3-27.

Epuran, M., \& Stănescu, M. (2010). Învățarea motrică - Aplicații în activitățile corporale [Motor learning Applications to bodily activities]. București: Discobolul.

Jeleașcov, C. (2006). Curs de dans sportiv [A dancesport course]. București: Editura Fundației România Mare.

Luca, A. (2010). Psihodiagnoza aptitudinilor şi inteligenţei [The psycho-diagnosis of skills and intelligence]. Retrieved from https://www.scribd.com/doc/25424914/Psihodiagnoza-Aptitudinilor-Si-Inteligentei

Mackrell, J. R. (2019). Dance - Performing Arts. In Encyclopedia Britannica. Retrieved from https://www.britannica.com/art/dance

Macovei, S. (2011). Bazele teoretice şi metodice ale gimnasticii aerobice de intretinere [Theoretical and methodological bases of aerobics for maintenance]. București: Discobolul.

Macovei, S. (2018). Kinantropologie. Particularități şi capacităţi motrice în ontogeneză - Note de curs [Kinanthropology. Particularities and motor abilities in ontogenesis - Course notes]. București: Discobolul.

Manno, R. (1992). Les bases de l'entraînement sportif [Foundations of sport training]. Paris: Revue EPS.

Mitrache, G., \& Tüdös, Șt. (2004). Psihomotricitate și limbaj [Psychomotricity and language]. București: Cartea Universitară.

Miclea, M., Porumb, M., Cotârle, P., \& Albu, M. (Coord.) (2009). CAS ${ }^{++}$Cognitrom Assessment System. ClujNapoca: ASCR.

Năstase, V. (2011). Dans sportiv - Metodologia performanței [Dancesport - Performance methodology]. Pitești: Paralela 45.

Şerbănoiu, S. (2002). Capacităţile de coordonare în sportul de performanţă [Coordination skills in performance sport]. București: Tipografia Făgăraş. 